\title{
Attributes of Quality of Accommodation Facilities and Room Capacity Utilization of 3-5 Star Hotels in Nairobi, Kenya
} \author{
Miricho $^{1 *}$, N. M., and Adedipe ${ }^{2 *}$, A. \\ ${ }^{1}$ Department of Hospitality, School of Hospitality, Tourism and Leisure, Kenyatta University, Nairobi, \\ Kenya \\ ${ }^{2}$ Department of Hospitality and Tourism, Federal University of Agriculture, Abeokuta, Ogun State, Nigeria.
}

\begin{abstract}
:
There are specific quality requirements usually established in accordance with standards at either government or private levels for hotel accommodation facilities. One of these basic requirements is high quality of accommodation facilities which supposed to anchor room capacity utilisation of 3-5 star hotels in Nairobi, Kenya. The attributes of quality of accommodation facilities comprised of room flooring, decorations, bed and beddings, lightings and heating, comfort of bedroom, cleanliness, comfort of bathroom, towels, furniture and furnishings, toiletries and amenities, space and ventilation of the rooms. However, hotels with more accommodation quality attributes are likely to attract higher and better room capacity utilisation. Therefore, the study sought to examine the relationship between quality of accommodation facilities and room capacity utilisation of 3-5 star hotels in Nairobi, Kenya. The study hypothesized that there is no significant relationship between quality of accommodation facilities and room capacity utilisation of 3-5 star hotels in Nairobi, Kenya. The target population involved all the 3-5 star hotels in Nairobi, Kenya. A census of hotel general manager and front office managers consisting of 62 respondents was conducted through stratification of all the hotels. Questionnaire was used as instruments for data collection with $91.9 \%$ response rate and the data collected were analyzed using descriptive statistics to determine variable characteristics while Pearson correlation was used to establish the pattern of relationship and association of the variables. Also, linear regression analysis was involved to determine the level of significant and test hypothesis. The Pearson correlation result $(\mathrm{r}=-0.513, \mathrm{p}=0.000)$ indicated that quality of accommodation facilities had a strong positive relationship and association with room capacity utilisation. The regression analysis coefficient $\mathrm{R}=0.791$ and adjusted squared coefficient $\mathrm{R}^{2}=0.523$ were recorded which implied that the study variables explained $52.3 \%$ of the variations of room capacity utilisation. The regression model revealed comfort of bedroom, comfort of bathroom, cleanliness and furniture, fittings/furnishings as the four attributes of quality of accommodation facilities that were significant variable predictors of room capacity utilisation. The null hypothesis was rejected as there is significant relationship between quality of accommodation facilities and room capacity utilisation. The study concluded that an improvement in quality of accommodation facilities will cause positive significant changes in room capacity utilisation. The study recommends improvement on comfort of bedroom, comfort of bathroom, cleanliness as well as furniture, fittings/furnishings for better room capacity utilisation of 3-5 star hotels in Nairobi, Kenya.
\end{abstract}

Keywords: Quality of facilities, room capacity utilisation, star rated hotels.

\section{Introduction}

Globally, there are more than 14 million accommodation facilities available to millions of customers across low, middle and upper hotels (Smith Travel Research, 2014). According to United National World Tourism Organisation (UNWTO) in 2014 , a total of 1,138 million international overnight hotel visitors were recorded and grew by $4.4 \%$ to reach a total of 1,184 million in 2015 (UNWTO, 2015). In the region of Africa, upper hotels account for almost 99,000 accommodation facilities and number of hotel rooms has increased and continuing on the rise across the continent. No doubt, the demand for quality accommodation facilities in the 
continent is undergoing a major trend over the past years (Tourism Business Africa, 2013). Kenya as the market leader in East Africa sub-region offers the highest numbers of hotel accommodation (Euromonitor, 2016, HospitalityNet, 2016). In Kenya, there are a number of hotel guest rooms and customers' demand for quality accommodation is growing rapidly (Miricho, 2013).

\section{Room Capacity Utilisation}

Room capacity utilisation is the measure of room supply efficiency which is derived by the number of available room nights over room nights used (Thrane, 2006; Zhang, Ye, \& Law, 2011; Miricho, 2013). Room capacity utilisation refers to efficient use of accommodation products and services which is regarded as an importance element of hotel accommodation operations. Hotels with more accommodation quality attributes will likely attract higher and better room capacity utilisation. The utilisation of accommodation facilities less than the capacity connotes lost opportunities which inversely may lead to depletion in the hotel returns.

Room capacity utilisation takes into cognisance the level of room occupancy and it is the recurrent use of accommodation facilities and services by customers. The key determinant of room capacity utilisation is frequency of usage of the accommodation facilities by the customers (Amman, 2001). However, an increase in room capacity utilisation will depend on improvements to the physical accommodation facilities, intangible aspects and atmosphere of the hotel (Lollar, 1990).

Also, room capacity utilisation of hotel accommodation facilities will depend on types of room and rates per room. The types of room offer by hotels may vary in grades, design, features and functions. Also, there are different room rate categories with variations offered by hotels and the different room rates are offered to attract different customers to help ensure room capacity utilisation (Chan and Mackenzie 2009). In view of the above, this study assumed that room capacity utilisation depends on attributes of quality of accommodation facilities of hotels. Thus, this study adopted quality of accommodation facilities as a measurement value of room capacity utilisation of 3-5 star hotels in Nairobi, Kenya.

\section{Attributes of Quality of Accommodation Facilities}

The attributes of quality of accommodation facilities include both tangible and intangible items and generally, there are some specific quality requirements for hotel accommodation facilities
(UNWTO, 2015). The attributes of quality of accommodation facilities in the hotels cover areas such as comfort of hotel bedroom, comfort of hotel bathroom, furniture, fittings and furnishings, bed/beddings, flooring/lightings and heating, decorations, towels, toiletries/amenities, space, ventilation and general cleanliness of the rooms (VisitEngland, 2011; AA Hotel Services, 2011). The quality of accommodation facilities should be more obvious in upper hotels (Israeli \& Uriely, 2000; Narangajavana \& $\mathrm{Hu}, 2008$; Whitelaw \& Jago, 2009).

In hotels, the facilities supposed to communicate high quality of accommodation standards (Kiplagat, Makindi \& Obwoyere, 2014). Andrews (2008) observed that hotel rooms should connote quality and comfort to the users in totality. A consistent higher quality and range of physical facilities should be offered across all areas however, there are cases where the quality of accommodation facilities of hotels did not correspond to room standards and utilisation (Fernandez \& Bedia, 2004; UNWTO, 2015). The quality of accommodation facilities is of paramount importance to all customers and it is expected that accommodation facilities of hotels will be of quality, comfort and clean (Opondo, 2014). A standard room will have a bed, bathroom facilities, shower, telephone, TV, lounge area, mini-bar and access to a wireless computer network and other essential business services (Chan et al., 2009). The EAC (2009) report shows that every room should have a clean and comfortable bed of not less than $190 \mathrm{~cm} \times 90 \mathrm{cms}$. Mattress should not be less than $15 \mathrm{cms}$ thick with two matching pillows and towels should be adequate and of good quality material, in good condition and changed daily.

\section{Hotels in Nairobi, Kenya}

The register of classified hotels for the period of 2015-2017 in Kenya indicated that Nairobi County registered thirty one (31) three, four and five star-hotels (TRAK, 2018). These hotels are considered as middle and upper class star rated hotels with high quality of accommodation facilities.

\section{Empirical Review of the study}

There are several related literature on room capacity utilisation including Gonzalez, Morini and Calatayud (1999); Slattery (2002); Capiez and Kava (2004); Law (2004); Ruggero (2011); Miricho (2013); Ivanov (2014) studies that identifies indicators of hotel room performance to comprise financial ratios, room occupancy, room prices, 
revenue per available room, sales growth and customer satisfaction. On the other hand, Barth (2002) suggests the use of three contribution based yield statistics ratios as basic performance indicators for hotels. These three defining ratios include room efficiency ratio (average room rates), capacity utilization ratio (occupancy) and earning optimization ratio (revenue per available room). However, Ruggero (2011) study states that hotel room performance outputs are usually related to revenues, occupancy or customer satisfaction.

Also, Santoro (2015) study revealed that hotel industry performance can be measured using occupancy performance. The study conducted by Miricho (2013) on yield management strategy, opportunities and scope in room-stock management affirmed that the only suitable traditional performance measure across all levels of hotel was capacity utilization measure of room occupancy. This is because room occupancy measurement values are common-sized across the star rated hotels into percentages.

Furthermore, other literature like the relationship between hotel room pricing, occupancy and guest satisfaction (Mattila \& O'Neill, 2003); the determinants of room rates for hotels in capital cities (Thrane, 2006) and factors influencing hotel occupancy (Ramjeesingh, Wright, \& Hayle, 2010) all focus on the relationship between room rate and occupancy. Also, the studies on determinants of hotel room price an exploration of travellers' hierarchy of accommodation needs (Zhang, Ye \& Law, 2011); internal success factor of hotel occupancy rate (Abdullah \& Hamdan, 2012) and factors affecting hotels occupancy rate (Al Saleem \& Al-Juboori 2013) concentrate only on issues of room rates, room pricing and occupancy with no reference made on the relationship between quality of accommodation facilities and room capacity utilisation of hotels.

On the other hand, the literature review on quality of room facilities includes the study conducted by Callan (1995) which reveals that rating schemes are beneficial to both the customers and hotels in improving the facilities and service quality. This study only made evaluation of the various hotel rating schemes with no reference to room capacity utilisation. The study by Opondo (2014) on quality evaluation and management practices of guest houses indicates a high rating on clean linen, guest supplies, well lit rooms, convenient location, comfortable bed, and friendliness and courtesy of staff, security and safety of the room. However, the study scope was only limited to guest houses and not related to hotels.

Barber and Scarcelli (2007) study on assessment of tangible quality through the creation of cleanliness reveals that cleanliness of the bedrooms and bathrooms are indicator of quality of facilities. Also, Scarcelli (2007) study reveals the cleanliness of the bathrooms is an indicator of quality of hotel facilities. The studies show that quality and cleanliness of facilities are important in the choice of a hotel by customers. Also, cleanliness of hotel bedrooms and bathrooms influences customer perception of service quality. Santoro (2015) study reveals that the quality of room facility is the first driver of performance in the hotels industry. The finding indicates that one of the attributes observable or tangible in a destination is the quality of hotel accommodation facilities. Moreover, Lopez (2004) study identifies that quality of room facilities associated well with hotel room capacity utilisation. Furthermore, Mutisya (2011) study indicates that room quality and comfort of guest rooms, high standards of cleanliness of bedrooms, bathrooms and bed linens are essential to guest delight. Above all, the various empirical reviews on quality of accommodation facilities are not related to room capacity utilisation of hotels.

\section{The Study Area}

The study was conducted in Nairobi County being the city with highest concentration of 3-5 star hotels in Kenya. Also, Nairobi County is the centre for both local and international managed hotels in Kenya.

\section{Objective of the Study}

The objective of this study is to examine the relationship between quality of accommodation facilities and room capacity utilisation of 3-5 star hotels in Nairobi, Kenya.

\section{Hypothesis of the Study}

There is no significant relationship between quality of accommodation facilities and room capacity utilisation of 3-5 star hotels in Nairobi, Kenya.

\section{Methodology}

For the purpose of this study, a crosssectional descriptive survey was used to collect data from the respondents and the design facilitates effective collection of quantitative data from the population under study. A structured close ended questionnaire was used and respondents were 
provided with the questionnaire to fill in the hotels. This was to enable the respondents to account for the attributes mentioned in the questionnaire and a total number of 62 respondents were involved using purposive and stratified sampling methods however, only 57 respondents properly completed and returned the questionnaire. The inclusion criterion of hotel general manager and front of managers was based on the fact that they provided critical, useful and relevant information concerning hotel accommodation matters (Rutherford \& O'Fallon, 2007).

The data collected were analyzed using appropriate software and descriptive statistics was used to determine variable characteristics of the study while Pearson correlation was used to establish the pattern of relationship and association of the study variables. Also, linear regression analysis was involved to determine the level of significant and the coefficient to test hypothesis of the study.

\section{Results and Discussion}

A total of 62 survey questionnaire was distributed and 57 questionnaire was properly filled with a $91.9 \%$ return rate from the hotel general manager and front office managers of 3-5 star hotels in Nairobi, Kenya. In Figure 1 are the results of room capacity utilisation of 3-5 star hotels in Nairobi, Kenya.

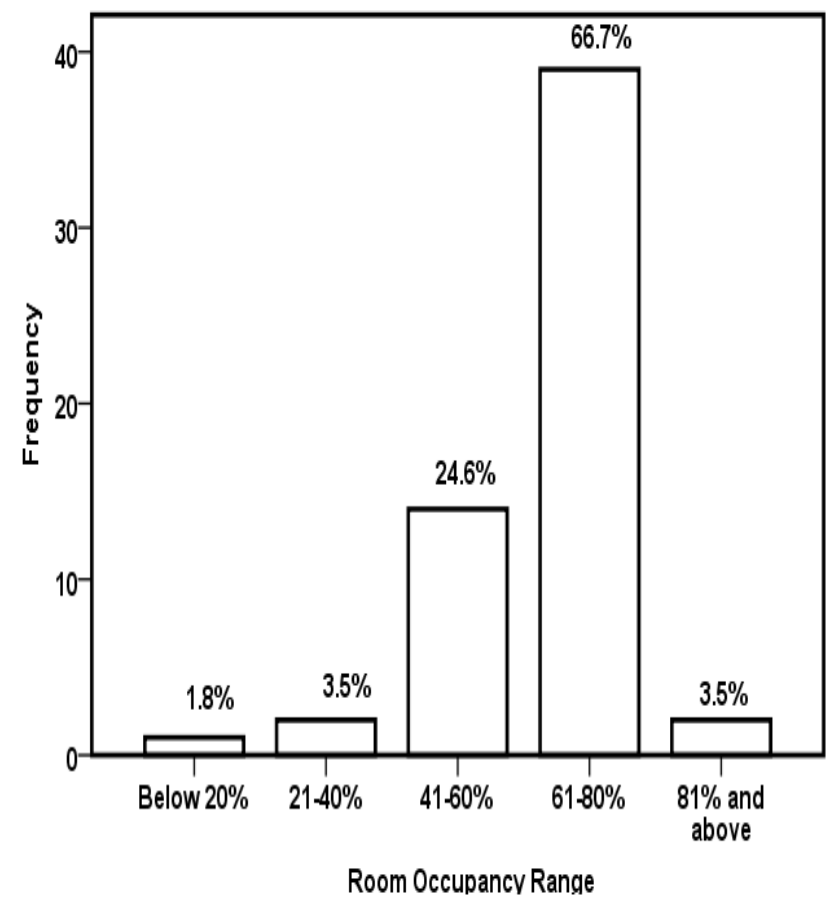

Figure 1: Room Capacity Utilization of Hotels Source: Survey (2017)

The room capacity utilisation results in Figure 1 revealed that $1.8 \%$ of the respondents indicated the room capacity utilisation was below $20 \%$ while $3.5 \%$ respondents concurred the room capacity utilisation was between 21-40\%. Furthermore, $24.6 \%$ respondents revealed the room capacity utilisation was between $41-60 \%$. Also, $66.7 \%$ respondents admitted the room capacity utilisation was between $61-80 \%$ while $3.5 \%$ respondents indicated the room capacity utilisation was above $81 \%$. The results revealed that majority of 3-5 star hotels in Nairobi, Kenya were operating within the range of $61-80 \%$ room capacity utilisation. This indicated that 3-5 star hotels in Nairobi, Kenya recorded high room capacity utilisation. The results tallied with Miricho (2013) report that hotel accommodation sector in Kenya was performing and growing at a rapid rate.

The descriptive analysis was based on the levels of importance and agreement of respondents regarding quality of accommodation facilities in relation to room capacity utilisation of 3-5 star hotels in Nairobi, Kenya. In Table 1 are the results of descriptive statistics on quality of accommodation facilities in relation to room capacity utilisation.

Table 1: Quality of Accommodation Facilities and Room Capacity Utilisation

\begin{tabular}{|c|c|c|c|c|c|c|c|c|}
\hline $\begin{array}{l}\text { Variable } \\
s \\
(\mathrm{~N}=57) \\
\end{array}$ & $\begin{array}{r}1 \\
\text { SD }\end{array}$ & \begin{tabular}{|l|}
2 \\
D
\end{tabular} & \begin{tabular}{|l|}
$\mathbf{3}$ \\
$\mathbf{N}$
\end{tabular} & $\begin{array}{l}\mathbf{4} \\
\mathrm{A}\end{array}$ & $\begin{array}{l}5 \\
\text { SA }\end{array}$ & Mean & S.D & $\begin{array}{l}\text { Rem } \\
\text { arks }\end{array}$ \\
\hline $\begin{array}{l}\text { Room } \\
\text { Floori } \\
\text { ng }\end{array}$ & $\begin{array}{l}1.8 \\
\%\end{array}$ & $\begin{array}{l}1.8 \\
\%\end{array}$ & $\begin{array}{l}3.5 \\
\%\end{array}$ & $\begin{array}{l}21 . \\
1 \%\end{array}$ & $\begin{array}{l}71.8 \\
\%\end{array}$ & 4.5965 & $\begin{array}{c}.7986 \\
5 \\
\end{array}$ & SA \\
\hline $\begin{array}{l}\text { Decor } \\
\text { ations }\end{array}$ & $\begin{array}{l}1.8 \\
\%\end{array}$ & $\begin{array}{l}1.8 \\
\%\end{array}$ & $\begin{array}{l}1.8 \\
\%\end{array}$ & $\begin{array}{l}3.5 \\
\%\end{array}$ & $\begin{array}{l}91.1 \\
\%\end{array}$ & 4.8070 & $\begin{array}{c}7181 \\
0\end{array}$ & SA \\
\hline $\begin{array}{l}\text { Beds } \\
\text { and } \\
\text { Beddi } \\
\text { ngs }\end{array}$ & $\begin{array}{l}1.8 \\
\%\end{array}$ & $\begin{array}{l}1.8 \\
\%\end{array}$ & $\begin{array}{l}1.8 \\
\%\end{array}$ & $\begin{array}{l}5.3 \\
\%\end{array}$ & $\begin{array}{l}89.3 \\
\%\end{array}$ & 4.7895 & $\begin{array}{c}.7254 \\
8\end{array}$ & SA \\
\hline $\begin{array}{l}\text { Lighti } \\
\text { ngs } \\
\text { and } \\
\text { Heatin } \\
\text { g }\end{array}$ & $\begin{array}{l}1.8 \\
\%\end{array}$ & $\begin{array}{l}1.8 \\
\%\end{array}$ & $\begin{array}{l}1.8 \\
\%\end{array}$ & $\begin{array}{l}31 . \\
5 \\
\%\end{array}$ & $\begin{array}{l}63.1 \\
\%\end{array}$ & 4.5263 & $\begin{array}{c}.7816 \\
0\end{array}$ & SA \\
\hline $\begin{array}{l}\text { Comfo } \\
\mathrm{rt} \text { of } \\
\text { Bed }\end{array}$ & $\begin{array}{l}1.8 \\
\%\end{array}$ & $\begin{array}{l}1.8 \\
\%\end{array}$ & $\begin{array}{l}1.8 \\
\%\end{array}$ & $\begin{array}{l}38 . \\
5 \%\end{array}$ & $\begin{array}{l}56.1 \\
\%\end{array}$ & 4.4561 & .7808 & SA \\
\hline
\end{tabular}




\begin{tabular}{|c|c|c|c|c|c|c|c|c|}
\hline room & & & & & & & 0 & \\
\hline $\begin{array}{l}\text { Cleanl } \\
\text { iness }\end{array}$ & $\begin{array}{l}1.8 \\
\%\end{array}$ & $\begin{array}{l}1.8 \\
\%\end{array}$ & $\begin{array}{l}1.8 \\
\%\end{array}$ & $\begin{array}{l}54 . \\
3 \%\end{array}$ & $\begin{array}{l}40.3 \\
\%\end{array}$ & 4.2982 & $\begin{array}{c}.7551 \\
0\end{array}$ & A \\
\hline $\begin{array}{l}\text { Comfo } \\
\mathrm{rt} \text { of } \\
\text { Bath } \\
\text { room }\end{array}$ & $\begin{array}{l}1.8 \\
\%\end{array}$ & $\begin{array}{l}1.8 \\
\%\end{array}$ & $\begin{array}{l}1.8 \\
\%\end{array}$ & $\begin{array}{l}33 . \\
8 \%\end{array}$ & $\begin{array}{l}61.3 \\
\%\end{array}$ & 4.5088 & $\begin{array}{c}.7820 \\
0\end{array}$ & SA \\
\hline $\begin{array}{l}\text { Towel } \\
\text { s }\end{array}$ & $\begin{array}{l}1.8 \\
\%\end{array}$ & $\begin{array}{l}1.8 \\
\%\end{array}$ & $\begin{array}{l}5.3 \\
\%\end{array}$ & $\begin{array}{l}54 . \\
4 \%\end{array}$ & $\begin{array}{l}36.7 \\
\%\end{array}$ & 4.2281 & $\begin{array}{c}.7796 \\
0\end{array}$ & $\mathrm{~A}$ \\
\hline $\begin{array}{l}\text { Furnit } \\
\text { ure, } \\
\text { Fitting } \\
\text { s and } \\
\text { Furnis } \\
\text { hings }\end{array}$ & $\begin{array}{l}1.8 \\
\%\end{array}$ & $\begin{array}{l}5.3 \\
\%\end{array}$ & $\begin{array}{l}5.3 \\
\%\end{array}$ & $\begin{array}{l}33 . \\
3 \%\end{array}$ & $\begin{array}{l}54.3 \\
\%\end{array}$ & 4.3333 & $\begin{array}{c}9322 \\
3\end{array}$ & SA \\
\hline $\begin{array}{l}\text { Room } \\
\text { Space }\end{array}$ & $\begin{array}{l}1.8 \\
\%\end{array}$ & $\begin{array}{l}1.8 \\
\%\end{array}$ & $\begin{array}{l}1.8 \\
\%\end{array}$ & $\begin{array}{l}49 . \\
1 \%\end{array}$ & $\begin{array}{l}45.5 \\
\%\end{array}$ & 4.3509 & $\begin{array}{c}.7674 \\
5\end{array}$ & A \\
\hline $\begin{array}{l}\text { Room } \\
\text { Ventil } \\
\text { ation }\end{array}$ & $\begin{array}{l}1.8 \\
\%\end{array}$ & $\begin{array}{l}1.8 \\
\%\end{array}$ & $\begin{array}{l}1.8 \\
\%\end{array}$ & 55. & $\begin{array}{l}49.1 \\
\%\end{array}$ & 4.3860 & $\begin{array}{c}.7735 \\
4\end{array}$ & SA \\
\hline $\begin{array}{l}\text { Toiletr } \\
\text { ies and } \\
\text { Ameni } \\
\text { ties }\end{array}$ & $\begin{array}{l}1.8 \\
\%\end{array}$ & $\begin{array}{l}1.8 \\
\%\end{array}$ & $\begin{array}{l}1.8 \\
\%\end{array}$ & $\begin{array}{l}10 . \\
4 \%\end{array}$ & $\begin{array}{l}84.2 \\
\%\end{array}$ & 4.7368 & .7446 & SA \\
\hline \multicolumn{6}{|c|}{ Average } & 1.5015 & 77827 & \\
\hline
\end{tabular}

Source: Survey (2017)

The results in Table 1 indicated an average mean score of 4.5015 and standard deviation of .77827 were recorded between quality of accommodation facilities and room capacity utilisation. The several strongly agree (SA) and agree (A) scores in all the attributes was an indication of availability of considerable levels of quality of accommodation facilities in 3-5 star hotels in Nairobi, Kenya.

The descriptive findings showed that quality of accommodation facilities were important variable in room capacity utilisation of 3-5 star hotels in Nairobi, Kenya. The findings tallied with
VisitEngland (2011); AA Hotel Services (2011) reports which indicated that quality of accommodation facilities were critical elements of room capacity utilisation. The findings also supported argument that a guest who booked hotel accommodation received more than just a room with a bed (Chan et al. 2009).

The results of Pearson Correlation Coefficient analysis correlation on the attributes of quality of accommodation facilities and room capacity utilisation of 3-5 star hotels in Nairobi, Kenya are as displayed in Table 2.

Table 2: Pearson Correlation on Attributes of Quality of Accommodation Facilities

\begin{tabular}{|l|l|l|}
\hline Variables & $\begin{array}{l}\text { Pearson } \\
\text { Correlation (r) }\end{array}$ & $\begin{array}{l}\text { Sig. (2- } \\
\text { tailed) }\end{array}$ \\
\hline Room Flooring & $.388^{* *}$ & .003 \\
\hline Decorations & $.533^{* *}$ & .000 \\
\hline Bed \& Beddings & $.546^{* *}$ & .000 \\
\hline $\begin{array}{l}\text { Lightings and } \\
\text { Heating }\end{array}$ & $.493^{* *}$ & .000 \\
\hline Comfort of Bedroom & $.617^{* *}$ & .000 \\
\hline Cleanliness & $.375^{* *}$ & .004 \\
\hline Comfort of Bathroom & $.564^{* *}$ & .000 \\
\hline Towels & $.432^{* *}$ & .001 \\
\hline $\begin{array}{l}\text { Furniture, Fittings \& } \\
\text { Furnishings }\end{array}$ & .137 & .309 \\
\hline Room Space & $.316^{* *}$ & .017 \\
\hline Room Ventilation & $.416^{* *}$ & .001 \\
\hline $\begin{array}{l}\text { Toiletries and } \\
\text { Amenities }\end{array}$ & $.500^{* *}$ & .000 \\
\hline $\begin{array}{l}* * \text { Correlation is significant at the } 0.01 \text { level (2- } \\
\text { tailed } \\
* \text { *. Correlation is significant at the } 0.05 \\
\text { tailed). level (2- }\end{array}$ \\
\hline
\end{tabular}

Source: Survey (2017)

The Pearson correlation results in Table 2 revealed the pattern of association between the attributes of quality of accommodation facilities. The results indicated a positive relationship and association between the attributes of quality of accommodation facilities and room capacity utilisation of 3-5 star hotels in Nairobi, Kenya. In Table 3 are the summary results of Pearson Correlation Coefficient analysis between quality of accommodation facilities and room capacity utilisation.

Table 3: Pearson Correlation on Quality of Accommodation Facilities and Room Capacity Utilisation

\begin{tabular}{|l|c|c|}
\hline & $\begin{array}{c}\text { Quality } \\
\text { of room }\end{array}$ & $\begin{array}{c}\text { Room } \\
\text { capacity }\end{array}$ \\
\hline
\end{tabular}




\begin{tabular}{|c|c|c|c|}
\hline & & $\begin{array}{c}\text { facilitie } \\
\text { s }\end{array}$ & $\begin{array}{c}\text { utilisatio } \\
n\end{array}$ \\
\hline \multirow{3}{*}{$\begin{array}{l}\text { Quality } \\
\text { of room } \\
\text { facilitie } \\
\text { s }\end{array}$} & $\begin{array}{c}\text { Pearson } \\
\text { Correlati } \\
\text { on }\end{array}$ & 1 & $.513^{* *}$ \\
\hline & $\begin{array}{l}\text { Sig. (2- } \\
\text { tailed) }\end{array}$ & & .000 \\
\hline & $\mathrm{N}$ & 57 & 57 \\
\hline \multirow{3}{*}{$\begin{array}{c}\text { Room } \\
\text { capacit } \\
y \\
\text { utilisati } \\
\text { on }\end{array}$} & $\begin{array}{c}\text { Pearson } \\
\text { Correlati } \\
\text { on }\end{array}$ & $.513^{* *}$ & 1 \\
\hline & $\begin{array}{l}\text { Sig. (2- } \\
\text { tailed) }\end{array}$ & .000 & \\
\hline & $\mathrm{N}$ & 57 & 57 \\
\hline
\end{tabular}

**. Correlation is significant at the 0.01 level (2-tailed).

Source: Survey (2017)

The Pearson correlation results in Table 3 revealed the pattern of association between quality of accommodation facilities and room capacity utilisation. The Pearson correlation coefficient results indicated a positive and strong significant association between the two variables $[\mathrm{r}=.513$, $\mathrm{p}=0.000]$. As quality of accommodation facilities increases so does room capacity utilisation. This meant that quality of accommodation facilities significantly correlate to room capacity utilisation of 3-5 star hotels in Nairobi, Kenya. The correlation analysis indicated that quality of accommodation facilities positively associated to room capacity utilisation of 3-5 star hotels in Nairobi, Kenya. The result $(\mathrm{r}=.513, \mathrm{n}=57, \mathrm{p}<.000)$ revealed that there was a strong positive correlation between quality of accommodation facilities and room capacity utilisation.

The coefficient of determination $\mathrm{r}=.513$ when squared meant 0.2632 shared variance of quality of accommodation facilities and room capacity utilisation. This revealed that quality of accommodation facilities explained $26.32 \%$ of the variance in scores on room capacity utilisation of 3-5 star hotels in Nairobi, Kenya. The positive correlation between study variables affirmed Santoro (2015) study on performance evaluation in hotel industry which recorded positive correlation between room facilities and hotel performance. Also, the findings concurred with the study of Lopez (2004) which identified that quality of room facilities associated well with hotel room performance.

The regression analysis was conducted to test the level of significance and determine the relationship between quality of accommodation facilities and room capacity utilisation. The results of the model summary are as presented in Table 4.

\section{Table 4: Model Summary}

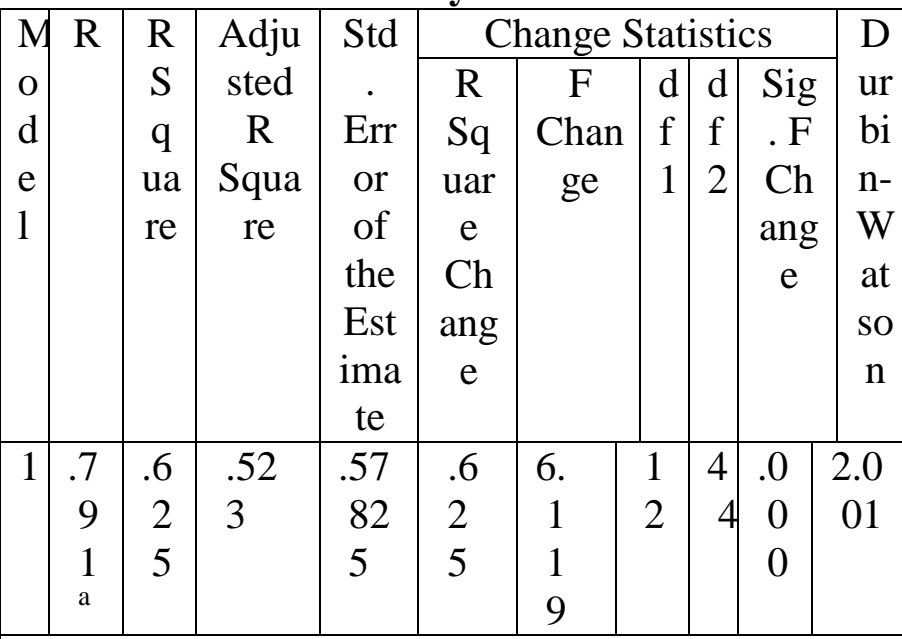

a. Predictors: (Constant),

Accommodation Facilities

b. Dependent Variable: Room Capacity Utilisation

\section{Source: Survey (2017)}

The regression model results in Table 4 revealed regression coefficient $\mathrm{R}$ of 0.791 supported by coefficient of determination $\mathrm{R}^{2}$ of 0.625 and adjusted $\mathrm{R}^{2}$ of 0.523 . This meant that the study variable explained $52.3 \%$ variations in the dependent variable namely room capacity utilisation. The model fitness indicated that quality of accommodation facilities was contributory variable in room capacity utilisation of 3-5 star hotels in Nairobi, Kenya. The results revealed that quality of accommodation facilities was contributory variable in room capacity utilisation. The results further deduced that there was a satisfactory link in relationship between the quality of accommodation facilities and room capacity utilisation. Also, the Durbin-Watson result of 2.001 met the assumption that errors in regression are independent if DurbinWatson statistic was close to 2 (and between 1 and 2 ). The results of the analysis of variance (ANOVA) are as presented in Table 5.

\section{Table 5: Analysis Of Variance (ANOVA)}

\begin{tabular}{|c|c|l|l|l|l|l|}
\hline \multicolumn{2}{|l|}{ Model } & \begin{tabular}{l} 
Sum \\
of \\
\multicolumn{2}{|l|}{} \\
\multicolumn{2}{|l|}{$\begin{array}{l}\text { Squar } \\
\text { es }\end{array}$}
\end{tabular} & $\begin{array}{l}\text { D } \\
\text { f }\end{array}$ & $\begin{array}{l}\text { Mea } \\
\text { Squa } \\
\text { re }\end{array}$ & F & Sig. \\
\hline \multirow{2}{*}{1} & Regression & 24.5 & 1 & 2.0 & 6.1 & $\begin{array}{l}.00 \\
\text { b } \\
\end{array}$ \\
\cline { 2 - 7 } & 51 & 2 & 46 & 19 & $0^{\text {b }}$ \\
\cline { 2 - 7 } & Residual & 14.7 & 4 & .33 & & \\
& 12 & 4 & 4 & & \\
\cline { 2 - 7 } & Total & 39.2 & 5 & & & \\
& 63 & 6 & & & \\
\hline
\end{tabular}

a. Dependent Variable: Room Capacity Utilisation b. Predictors: (Constant), Quality 
Accommodation Facilities

Source: Survey (2017)

The results of Analysis of Variance (ANOVA) in Table 5 indicated an $\mathrm{F}$ statistics of 6.119 and $p$ value of 0.000 which is less than the conventional significance level $p=<0.05$. This meant that the regression model was statistically significant. Furthermore, the result indicated that the study variable of quality of accommodation facilities is relevant predictor of room capacity utilisation. The results of the linear regression analysis are as shown in Table 6.

TABLE 6: Linear Regression Analysis on the Study Variables

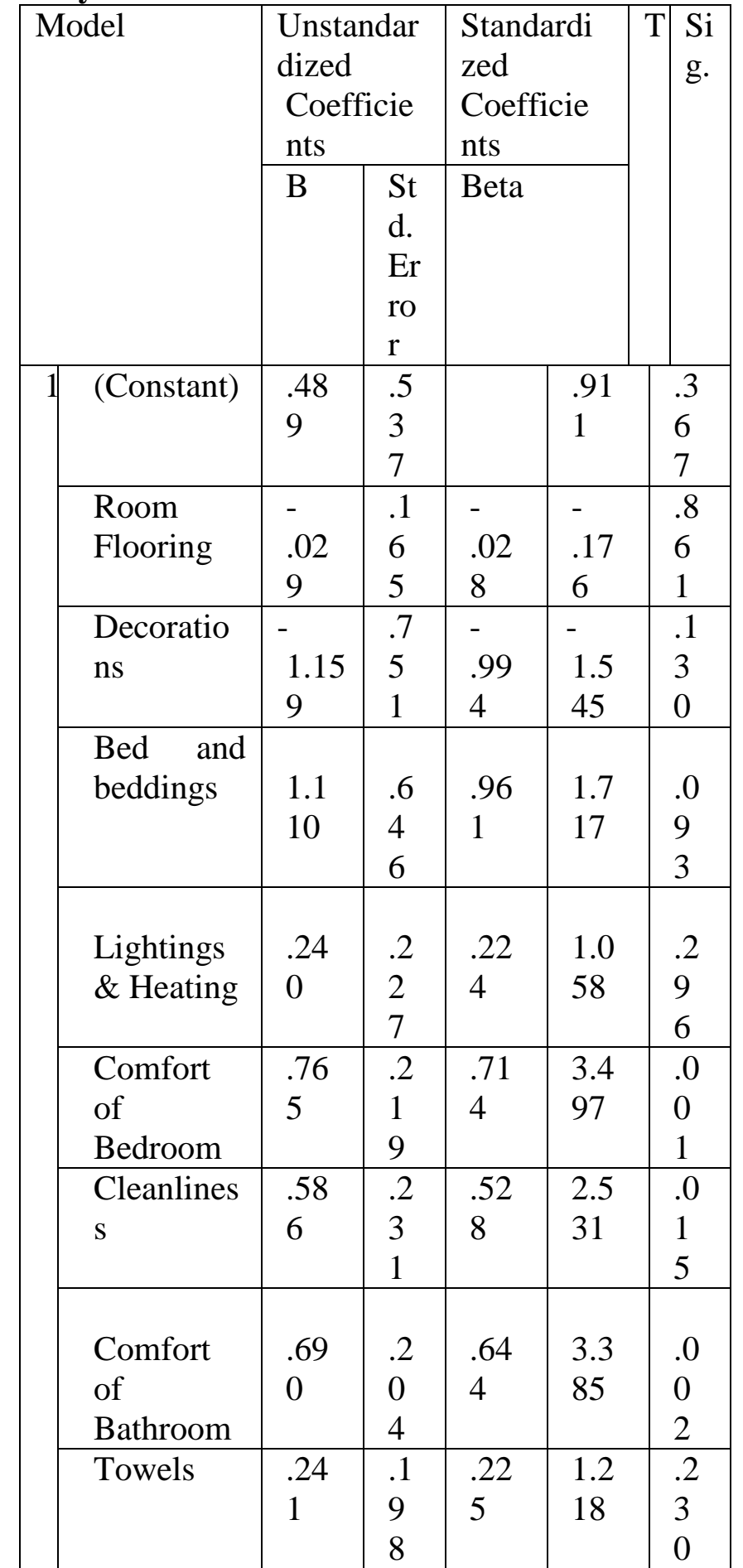

\begin{tabular}{|l|l|l|l|l|l|}
\hline Furniture, & & & & & \\
Fittings \& & .32 & .1 & .36 & 2.5 & .0 \\
Furnishing & 7 & 3 & 4 & 31 & 1 \\
$\mathrm{~s}$ & & 0 & & & 5 \\
\hline Space & - & .2 & - & - & .6 \\
& .09 & 1 & .09 & .45 & 5 \\
& 9 & 7 & 1 & 6 & 0 \\
\hline Ventilatio & .31 & .2 & .29 & 1.5 & .1 \\
$\mathrm{n}$ & 7 & 1 & 3 & 00 & 4 \\
& & 2 & & & 1 \\
\hline Toiletries & & & & & \\
$\&$ & .01 & .2 & .01 & .04 & .9 \\
Amenities & 1 & 7 & 0 & 2 & 6 \\
& & 0 & & & 6 \\
\hline
\end{tabular}

a. Dependent Variable: Room Capacity Utilisation

Source: Survey (2017)

The results of linear regression analysis in Table 6 revealed the model parameters. The twelve predictors (room flooring, decorations, bed and beddings, lightings and heating, comfort of bedroom, cleanliness, comfort of bathroom, towels, furniture/fittings and furnishings, space, ventilation and toiletries/amenities) were included in the model and the estimated contributions of the predictor beta (b) values to the model were determined. Also, the estimated contributions of the individual predictor beta $(b)$ values to the model were determined. Thus, the outcome of the model was defined as:

Room capacity utilisation $=\left(b_{0}\right.$ constant $)+\left(b_{1}\right.$ comfort of bedroom $)+\left(b_{2}\right.$ comfort of bathroom $)+$ $\left(b_{3}\right.$ cleanliness $)+\left(b_{4}\right.$ furniture, fittings and furnishings). Therefore, Room capacity utilisation $=$ $(0.489)+(0.765$ comfort of bedroom $)+(0.690$ comfort of bathroom $)+(0.586$ cleanliness $)+(0.327$ furniture, fittings and furnishings). Since the $b$ values of the four variables were positive, therefore, there was a significant positive relationship between the predictors (comfort of bedroom, comfort of bathroom, cleanliness and furniture, fittings and furnishings) and the outcome (room capacity utilisation). This inferred that, an improvement in the predictors will lead to improvement in the outcome as follows:

Comfort of bedroom $\left(b_{1}=0.765\right)$ :- This value indicated that, increase in the comfort of bedroom will lead to increase in room capacity utilisation if other predictors remain constant. Comfort of bathroom $\left(b_{2}=0.690\right)$ :- This value indicated that, increase in comfort of bathroom will lead to increase in room capacity utilisation if other predictors remain constant. Cleanliness $\left(b_{3}=\right.$ 0.586):- This value indicated that, increase in cleanliness will lead to increase in room capacity 
utilisation if other predictors remain constant. Furniture, fittings and furnishings $\left(b_{4}=0.327\right)$ :- This value indicated that, increase in furniture, fittings and furnishings will lead to increase in room capacity utilisation if other predictors remain constant.

The standardized $b$-value on the level of importance of the predictors revealed comfort of bedroom recorded 0.714 , comfort of bathroom 0.644 , cleanliness 0.528 and furniture, fittings and furnishings 0.364 . Also, the standard error indicated the extent to which the coefficient differed significantly from zero using an alpha of 0.05 . The $\mathrm{p}$-values of the four predictors, comfort of bedroom 0.001 , comfort of bathroom 0.002 , cleanliness 0.015 and furniture, fittings and furnishings 0.015 were significantly different from zero and less than 0.05 .

Therefore, a model was achieved by removing the predictor variables not within $\mathrm{p} \leq 0.05$ significant level. The model outcomes are as displayed in Table 7.

Table 7: Study Regression Model

\begin{tabular}{|c|c|c|c|c|c|c|}
\hline \multirow[t]{2}{*}{ Model } & \multicolumn{2}{|c|}{$\begin{array}{l}\text { Unstandar } \\
\text { dized } \\
\text { Coefficie } \\
\text { nts }\end{array}$} & \multirow{2}{*}{\multicolumn{2}{|c|}{$\begin{array}{l}\text { Standardi } \\
\text { zed } \\
\text { Coefficie } \\
\text { nts } \\
\text { Beta }\end{array}$}} & & $\begin{array}{l}\mathrm{Si} \\
\text { g. }\end{array}$ \\
\hline & B & $\begin{array}{l}\mathrm{St} \\
\mathrm{d} . \\
\mathrm{Er} \\
\mathrm{ro} \\
\mathrm{r}\end{array}$ & & & & \\
\hline (Constant) & $\begin{array}{l}.48 \\
9\end{array}$ & $\begin{array}{l}.5 \\
3 \\
7\end{array}$ & & $\begin{array}{l}.91 \\
1\end{array}$ & , & \\
\hline $\begin{array}{l}\text { Comfort } \\
\text { of } \\
\text { Bedroom }\end{array}$ & $\begin{array}{l}.76 \\
5\end{array}$ & $\begin{array}{l}.2 \\
1 \\
9 \\
\end{array}$ & $\begin{array}{l}.71 \\
4\end{array}$ & $\begin{array}{l}3.4 \\
97\end{array}$ & i & \\
\hline $\begin{array}{l}\text { Comfort } \\
\text { of } \\
\text { Bathroom }\end{array}$ & $\begin{array}{l}.69 \\
0\end{array}$ & $\begin{array}{l}.2 \\
0 \\
4\end{array}$ & $\begin{array}{l}.64 \\
4\end{array}$ & $\begin{array}{l}3.3 \\
85\end{array}$ & i & \\
\hline $\begin{array}{l}\text { Cleanlines } \\
\text { s }\end{array}$ & $\begin{array}{l}.58 \\
6\end{array}$ & $\begin{array}{l}.2 \\
3 \\
1\end{array}$ & $\begin{array}{l}.52 \\
8\end{array}$ & $\begin{array}{l}2.5 \\
32\end{array}$ & 5 & \\
\hline $\begin{array}{l}\text { Furniture, } \\
\text { Fittings \& } \\
\text { Furnishing } \\
\text { s }\end{array}$ & $\begin{array}{l}.32 \\
7\end{array}$ & $\begin{array}{l}.1 \\
3 \\
0\end{array}$ & $\begin{array}{l}.36 \\
4\end{array}$ & $\begin{array}{l}2.5 \\
27\end{array}$ & 5 & 0 \\
\hline
\end{tabular}

a. Dependent Variable: Room Capacity Utilisation
Source: Survey (2017)

The model in Table 7 indicated that comfort of bedroom, comfort of bathroom, cleanliness and furniture, fittings and furnishings were four significant variable predictors of room capacity utilisation of the study. The study variables of room flooring, decorations, bed and beddings, lightings and heating, towels, space, ventilation and toiletries/amenities were not significant predictors of room capacity utilisation of the study.

\section{Test of Hypothesis}

The t-test statistics results on quality of accommodation facilities are as indicated in Table 8.

\section{Table 8: T-Test Statistics on Quality of Accommodation Facilities}

\begin{tabular}{|l|l|l|l|l|l|}
\hline & B & \multicolumn{1}{l|}{$\begin{array}{l}\text { Std. Error } \\
\mathrm{T}\end{array}$} & Beta & $\begin{array}{l}\text { Si } \\
\mathrm{g}\end{array}$ \\
\hline $\begin{array}{l}\text { Quality of } \\
\text { accommo } \\
\text { dation } \\
\text { facilities }\end{array}$ & .054 & .012 & .5 & 4.4 &. \\
& & 1 & 35 & 0 \\
& & 3 & & 0 \\
& & & & \\
\hline \\
$\begin{array}{l}\text { a. Dependent Variable: Room Capacity } \\
\text { Utilisation }\end{array}$ \\
\hline
\end{tabular}

Source: Survey (2017)

The standardized $b$-value in Table 8 on the level of importance of the predictor revealed quality of accommodation facilities recorded 0.513. Also, the standard error indicated the extent to which the coefficient differed significantly from zero using an alpha of 0.05 . The coefficient for quality of accommodation facilities of 0.513 was significantly different from zero because the p-value of 0.000 was less than 0.05 . The linear regression indicated that there was a positive significant relationship between the quality of accommodation facilities and room capacity utilisation. This meant that, the more the quality of accommodation facilities provided the higher the level of capacity utilisation of the hotel. This finding is in line with Santoro (2015) study that identified quality of room facilities as a significant factor of performance in the hotels industry.

In testing the hypothesis of the study, the ttest statistics outcome of the regression coefficient was used. The null hypothesis $\left(\mathrm{H}_{\mathrm{O} 1}\right)$ stated that, there is no significant relationship between the quality of accommodation facilities and room capacity utilisation of 3-5 star hotels in Nairobi, Kenya. The alternate hypothesis $\left(\mathrm{H}_{\mathrm{a} 1}\right)$ stated that, there is a significant relationship between quality of 
accommodation facilities and room capacity utilisation of 3-5 star hotels in Nairobi, Kenya. Thus;

$\mathrm{H}_{\mathrm{O} 1}: \mathcal{B}_{1}=0$ (there is no significant relationship between the quality of accommodation facilities and room capacity utilisation of 3-5 star hotels in Nairobi, Kenya).

$\mathrm{H}_{\mathrm{a} 1}: \mathcal{B}_{1} \neq 0$ (there is significant relationship between quality of accommodation facilities and room capacity utilisation of 3-5 star hotels in Nairobi, Kenya).

Therefore, the $t$-statistics and $p$-value of quality of room facilities indicated $t=4.435 \mathrm{p}$-value $=0.000$. Since the $p$-value $=0.000 \leq 0.05$, the study rejected null hypothesis and accepted alternate hypothesis. Therefore, "there is a significant relationship between quality of accommodation facilities and room capacity utilisation of 3-5 star hotels in Nairobi, Kenya". This meant that quality of accommodation facilities related significantly to room capacity utilisation of 3-5 star hotels in Nairobi, Kenya. This is in line with Santoro (2015) study that identified quality of room facilities as a significant factor of performance in hotel industry.

\section{Conclusion}

This finding revealed that comfort of bedroom, comfort of bathrooms, cleanliness and furniture, fittings and furnishings of accommodation facilities constituted a significant predictor of room capacity utilisation of 3-5 star hotels in Nairobi, Kenya. The hotel operators should place more importance on improving the attributes of quality of accommodation facilities in terms of comfort of bedroom, comfort of bathrooms, cleanliness and furniture, fittings and furnishings of the rooms. Therefore, hotel managers should consider these four significant variables of quality of accommodation facilities as important and good predictors of room capacity utilisation of 3-5 star hotels in Nairobi, Kenya.

\section{Recommendations}

The hotel operators should consistently improve on comfort of bedroom, comfort of bathrooms, cleanliness and furniture, fittings and furnishings of the accommodation facilities to better room capacity utilisation of 3-5 star hotels in Nairobi, Kenya.

\section{References}

[1] AA Hotel Services. (2011). Hotel Quality Standards. Hampshire: AA Media Limited, Hampshire. Retreived from http:www.aa_hotel_quality_standards.pdf [Accessed on 8th February, 2016].

[2] Abdullah, A. A., \& Hamdan, H. M. (2012). Internal Success Factor of Hotel Occupancy Rate. International Journal of Business and Social Science, 3 (22), 199-218.

[3] Al Saleem, A. S., \& Al-Juboori, N. F. (2013). Factors Affecting Hotels Occupancy Rate (An Empirical Study on Some Hotels in Amman). Interdisciplinary Journal of Contemporary Research in Business, 5 (6), 142-159.

[4] Amman, R. (2001). Estimating the impact of economic factors on tourism: evidence from Hong Kong. Tourism Economics, Vol.7 (3), 277-293.

[5] Andrews, S. (2008). Textbook of Hotel, Housekeeping Management \& Operations. NewDelhi: McGraw-Hill.

[6] Barber, N., \& Scarcelli, J. M. (2010). Enhancing the Assessment of Tangible Service Quality through the Creation of Cleanliness. Managing Service Quality. 20 (1)

[7] Barth, J. (2002). Yield management: opportunities for club managers. International Journal of Contemporary Hospitality Management, Vol.14 (3), 136141.

[8] Callen, R. J. (1995). Hotel classification and grading schemes, a paradigm of utilization and user characteristics. International Journal of Hospitality Management, 14 (4), pp. 271-283.

[9] Capiez, A., \& Kava, A. (2004). Yield management and performance in the hotel industry. Journal of Travel and Tourism Marketing. Vol.16 (4), 21-32.

[10] EAC. (2010). Standards Criteria for Classification of Hotels, Restaurants and other Tourist Accommodation Facilities in East Africa. East African Community Gazette, Uganda Printing and Publishing.

[11] Euromonitor. (2016). Kenya Country Fact file. Euromonitor International. Retrieved from http:www.euromonitor.org [Accessed on 9th February, 2016].

[12] Fernandez, M. C., \& Bedia, A. M. (2004). Is the hotel classification system a good indicator of hotel quality? An application in Spain. Tourism Management, Vol. 25, pp.771-775.

[13] Gonzalez, J. I., Morini, S., \& Calatayud, F. P. (1999). How to cover risk in the Hotel 
sector. Annals of Tourism Research, Vol.26 (3), 709-712.

[14] Israeli, A. A., \& Uriely, N. (2000). The impact of star ratings and corporate affiliation on hotel. Journal of Tourism and Hospitality Research, 2 (1), pp.27-36.

[15] Ivanov, S. (2014). Hotel Revenue Management: From Theory to Practice. Varna: Zangador.

[16] Kiplagat, W. K., Makindi., S., \& Obwoyere, G. O. (2014). An analysis of hotel rating and its implication on financial turnover of rated hotels in kenya. International Journal of Environment, Ecology, Family and Urban Studies (IJEEFUS), Vol. 4 (3).

[17] Law, R. (2004). Initially testing an improved Extrapolative Hotel room occupancy rate forecasting technique. Journal of Travel and Tourism Marketing, Vol.16 (2), pp.71-77.

[18] Lollar, C. (1990). The Hotel Rating Game. Travel and Leisure, Vol. 20 (7), pp.64-67.

[19] Lopez, M. H. (2004). Future tourists' characteristics and decision: the use of genetic algorithms as a forecast method. Tourism Economics, 10 (3), pp.245-262.

[20] Mattila, A. S., \& O'Neill, J. W. (2003). Relationships between Hotel Room Pricing, Occupancy, and Guest Satisfaction: A Longitudinal Case of a Midscale Hotel in the United State. Journal of Hospitality \& Tourism Research, Vol. xx, No. x, pp.1-15.

[21] Miricho, M. N. (2013). Yield management strategy in Kenya's town hotels: opportunities and scope in room-stock management. PhD Research Thesis. Nairobi, Kenya: Kenyatta University.

[22] Mutisya, M. (2011). Customer satisfaction and loyalty in the application of the allinclusive holiday concept at the Kenyan Coast. PhD Research Thesis. Nairobi: Kenyatta University.

[23] Narangajavana, Y., \& Hu, B. O. (2008). The Relationship Between the Hotel Rating System, Service Quality Improvement, and Hotel Performance Changes: A Canonical Analysis of Hotels in Thailand. Journal of Quality Assurance in Hospitality \& Tourism, Vol 9 (1) 34 -56.

[24] Opondo, J. A. (2014). Service quality evaluation and management practices of guest houses in Mombasa Island, Kenya. PhD Research Thesis. Nairobi: Kenyatta University.
[25] Ramjeesingh, D., Wright, A., \& Hayle, C. (2010). Factors Influencing Hotel Occupancy in Jamaica: the Role of Events 1991-2008. Tourism Analysis, Vol. 15.

[26] Ruggero, S. (2011). RevPAR determinants of individual hotels: Evidences from Milan. International Journal of Contemporary Hospitality Management, Vol.23 (3), pp.297-311.

[27] Rutherford, D., \& O'Fallon, M. J. (2007). Hotel management and operations. Fourth edition. Hoboken, New Jersey: John Wiley \& Sons, Inc.

[28] Santoro, G. (2015). Evaluating Performance in the Hotel Industry: An Empirical Analysis of Piedmont. Special Issue: Attractiveness and Governance of Tourist Destinations. Journal of Investment and Management, Vol. 4 (1).

[29] Scarcelli, J. (2007). Clean Restaurant Restrooms: Do They Indicate a Clean Kitchen? Published Master s Thesis. West Latayette: Purdue University.

[30] Slattery, P. (2002). Reported ReVPAR: Unreliable Measure, Flaws Interpretations and the Remedy. International Journal of Contemporary Hospitality Management, 21 (4), pp.135-149.

[31] Smith Travel Research. (2014). African Economic Outlook. global rankings. STR. Retrieved from www.africaneconomicoutlook.org [Accessed on 14th February, 2016].

[32] Thrane, C. (2006). Examining the determinants of room rates for hotels in capital cities: The Oslo experience. Journal of Revenue and Pricing Management, 5 (4), pp.315-323.

TRAK, (2017). Tourism Regulatory

Authority, Kenya.

www.tourismregulatoryauthority.org. [Accessed on 10th July, 2017].

[34] UNWTO. (2015). Hotel Classification Systems: Recurrence of criteria in 4 and 5 stars hotels. Madrid, Spain: United Nation World Tourism Organization (UNWTO). Retrieved from http:www.unwto.org [Accessed on 26th July, 2016].

[35] VisitEngland. (2011). Hotel Accommodation Quality Standard. London: VisitEngland. Retrieved from http:www.visitengland.org [Accessed on 8th February, 2016].

[36] Whitelaw, P. A., \& Jago, L. (2009). Understanding the Key Elements of Star 
Ratings in Accommodation. Queensland, Australia: CRC for Sustainable Tourism Pty Ltd.

[37] Zhang, Z., Ye, Q., \& Law, R. (2011). Determinants of hotel room price: An exploration of travelers' hierarchy of accommodation needs. International Journal of Contemporary Hospitality Management, 23 (7), pp.72-98. 